\title{
Role of Plant Somatic Embryogenesis Receptor Kinases (SERKs) in Cell-to-Embryo Transitional Activity: Key at Novel Assorted Structural Subunits
}

\author{
Dhananjay Kumar Pandey, Bhupendra Chaudhary \\ School of Biotechnology, Gautam Buddha University, Greater Noida, India \\ Email: bhupendrach@gmail.com
}

Received 1 August 2014; revised 9 September 2014; accepted 13 October 2014

Copyright (C) 2014 by authors and Scientific Research Publishing Inc.

This work is licensed under the Creative Commons Attribution International License (CC BY). http://creativecommons.org/licenses/by/4.0/

(c) (i) Open Access

\begin{abstract}
Somatic Embryogenesis Receptor Kinase (SERK) family of receptor kinases is functionally diverse, involved in cell-to-embryo transition and controlling a number of other fundamental aspects of plant development. The morphological transformation of somatic to embryonic cells has drawn scientific attention utmost due to remarkable genetic-switch system evolved across species. Receptor kinases having direct role in somatic embryogenesis (SE) and involved in other functions are designated as "SERK" and "SERK-like" genes, respectively. We aim for phylogenetic reconstruction to reveal major SERK groups across plant species (angiosperm to gymnosperm) for their functional diversification. Data indicate that the development of SERK proteins occurred prior to the divergence of monocots and eudicots. Also, the SERK orthology is not directly proportional to their functions. Structure prediction results identified novel transmembrane topologies, short linear motifs and 0-glycosylation sites exclusively in SERK proteins than SERK-like proteins. Comparative temporal expression analyses of SERK and SERK-like genes provided significant accordance with their physiological function. The identification of intrinsic disordered regions (IDRs) exclusively in SERK proteins was assumed to perceive external stress-induced signals that may lead to rapid protein folding. In a result it switches-on the precise cellular signals essential for the acquisition of SE. Moreover, the regulatory sequences of SERK genes are evolved with unique cellular fate deciding AP2-like ethylene responsive transcription factor AINTEGUMENTA binding sites for their spatial expression in SE. Based on these analyses we suggest future avenues of research that may be imperative for elucidating the importance of SERK gene evolution in SE.
\end{abstract}

\section{Keywords}

Somatic Embryogenesis, Cell-Signalling, SERK, Evolution

How to cite this paper: Pandey, D.K. and Chaudhary, B. (2014) Role of Plant Somatic Embryogenesis Receptor Kinases (SERKs) in Cell-to-Embryo Transitional Activity: Key at Novel Assorted Structural Subunits. American Journal of Plant Sciences, 5, 3177-3193. http://dx.doi.org/10.4236/ajps.2014.521334 


\section{Introduction}

Among plant species, somatic embryogenesis (SE) is the transition of a somatic cell into embryonic cell that subsequently develops in to a somatic pro-embryo. Plant SE is one of the finest paradigms of developmental plasticity in which single cell destined for division comparable to its primogenitor, suddenly alter the developmental path and ensue towards embryogenesis. In general, SE involves with three distinct stages during embryo development including globular, heart-shaped and torpedo-shaped stage in dicot; globular, scutellar, and coleoptilar stages in monocots [1] [2]. Somatic embryogenesis harbours various resemblances with zygotic embryogenesis also at morphological and genetic levels making it a model system for studying different biochemical, morphological and physiological characteristics in higher plants [3]. Although, all somatic cells have a potential of embryonic transition, very few respond to such transformation and that may be accounted for either lack of key triggering intermediates or unavailability of suitable inducing micro-environment. Henceforth to date SE has been reported from a limited number of plant species with varied response of different tissue/explants in the standardized microclimatic conditions.

Somatic embryogenesis is extraordinarily complex and multistep process [4], in which various factors remain involved to make cellular milieu compatible to the acquisition of SE. Thousands of differentially expressed genes contribute to each stage of SE, although only a small number are known to be specifically involved in this complex developmental process defining the cell-fate. Sequential and compatible atmosphere is believed to be required during each developmental stage of embryogenesis and various factors help in the regulation of such sub-stage transition during the entire process of SE. In the initial developmental stage, differentiated somatic cell acquires embryogenic competence either directly without a de-differentiation or through indirect mode of callusing. In the latter, the somatic cell initially losses its identity and perceives an appropriate stimulus bring competency for SE induction. Subsequently, the somatic embryos enrolled into maturation phase anticipating germination by desiccation and reserve accumulation [5]. The SE must therefore consist of replacement of the existing pattern of gene expression in the explant tissues for a new embryogenic gene expression program [6] [7]. Probably cells acquire competence after responding to the appropriate signals and up-regulating different regulatory factors. Research studies highlighting the molecular and genetics basis of SE are vastly incoherent and largely dependent upon the genotype/cultivar, tissue type, physiological conditions of the donar plant and varied cultural regimes [2]. Generally, it is assumed that the intricate process of SE has been induced by abiotic stress conditions in the culture-microenvironment. This condition may include wounding, micro-nutrient supply, osmotic stress and hormonal treatment [7]-[12]. The latter has been shown to be the foremost constrain through up-regulation of cell-signalling processes in the competent somatic cells. However, still an important concern is to define the most precise and prevalent targets of such stress condition in SE.

The endogenous and exogenous auxin levels have direct correlation with various stress-induced factors and genes which has been observed up-regulated during the initiation and progression of SE [13] [14]. Auxin has been reported to be an important factor involved with the up-regulation of cell-signalling genes [15]. The conversion of a normal somatic cell into an embryo is reliant on a molecular switch in the existing signalling cascade. Such re-programming could however, occur either at alternatively or simultaneously at transcriptional and post-transcriptional levels or at both. It has been earlier reported [16] that SE requires high active RNA synthesis when switched to embryogenic cell proliferation. Therefore, identification and characterization of signalling candidate genes and trans-factors will highly contribute to our understanding the molecular basis of cell-to-embryo transition. Signalling genes and transcription factors specifically expressed during embryogenic stage could also be used as competent marker for the cell-fate change.

The SERK gene is one of the potential candidate genes those have been revealed for their direct role in SE induction [6]. The SERK molecules were first identified in Daucus carota cell cultures expressed in highly vacuolated cells. The expression of SERK gene was detected in somatic embryos upto globular stage of embryo development [17] [18]. Over expression of SERK gene led to 3-to-4 fold increase in the embryogenic competence and cell-to-embryo transition [19]. After the identification of SERK gene from Daccus, homologous genes were reported from A. thaliana (AtSERK1) [19] [20]; Cocos nucifera (CnSERK) [21]; Citrus unshiu (CuSERK1) [22]; Dactylis glomerata (DgSERK) [23]; Helianthus annus (HaSERK) [24]; Medicago trancatula (MtSERK) [25]; Oryza sativa (OsSERK) [26]; Solanum tuberosum (StSERK1) [27]; Theobroma cacao (TcSERK) [28]; Triticum aestivum (TaSERK) [29] and Vitis vinifera (VvSERK) [30] with their role in the induction of SE. The over-expression of SERKs at the cell surface involves in the production of several other molecular signals which act as ligand to the cell surface receptors. These ligands when bind to extracellular domain of SERK protein mediated 
by LRR region induces signaling cascade inside the cell. This signal through different sub-steps ultimately targets the nucleus and helps in alteration of the existing gene expression pattern and the cellular or molecular alterations possibly via chromatin remodeling enhance the expression of other somatic embryogenic inducing genes e.g. LEA, LEC, BBM and combined effect of these all compel a somatic cell to embryo transition [6] [18] [30]-[38]. With this data, it is very clear that SERK-mediated response of varied gene expression pattern may be the key for the somatic cell-to-embryo transition of a plant cell. Nonetheless more variants of SERK gene have been identified involved in the metabolic activities such as brassinosteroid pathway for resistance trait, pollen wall formation and in the reproductive organs highlighting the multi-function of SERK-mediated signaling [39]; and are not related to SE by any means. Therefore, receptor kinases having direct role in SE, and involved in other functions are designated as "SERK" and "SERK-like" gene, respectively hereinafter. Comparison of $S E R K$ and SERK-like genes/proteins at structural and regulatory levels would contribute to our understanding of the key changes evolved in the receptor kinases and are accountable for the orientation of cell-signaling during SE.

\section{Materials and Methods}

\subsection{Analysis of Transmembrane Topology and Signal Peptide}

Phobius online platform (http://phobius.sbc.su.se/) was used for transmembrane topology and signal peptide analysis in the AtSERK1 (AEE35238.1), AtSERK4 (AEC06259) and MtSERK1 (AAN64294.1). The protein sequences in FASTA format for each were obtained from NCBI protein database as already mentioned above and directly submitted to the Phobius online platform (http://phobius.sbc.su.se/). The prediction is based on a Hidden Markov Model (HMM) and algorithm called N-best performing the different sequence regions of a signal peptide and the different regions of a transmembrane protein in a series of interconnected states [40]. It reduces the chance of false classifications of transmembrane helices and signal peptides. In comparison to TMHMM and SignalP programmes [40] where often signal peptides are predicted as TM helices by mistake.

\subsection{Analysis of Short Linear Motifs}

AtSERK1, AtSERK4 and MtSERK1 protein sequences were obtained from NCBI protein database. AtSERK1 protein sequence obtained from NCBI which has reported as marker for SE were analysed with comparative analysis of AtSERK4 (non significant for SE) using “Eukaryotic Linear Motif” (ELM) resource at (http://elm.eu.org) which is a comprehensive database of known experimentally validated motifs, and an exploratory tool to discover putative linear motifs published very recently it uses different logical filters (or rules) based on context information to discriminate between likely true and false positives to predict accurately [41]. For, further validation, MtSERK1 (highly significant in SE) protein sequence were also analysed for short linear motifs using the same parameter of analysis on ELM resource platform.

\subsection{Analysis of Glycosylation Sites}

NetOGlyc3.1 online server (http://www.cbs.dtu.dk/services/NetOGlyc/) was used for the prediction of glycosylation pattern in the AtSERK1, AtSERK4 and MtSERK1 protein sequences. For pattern recognition NetOGlyc3.1 online server is based on artificial neural networks and weight matrix algorithms to determine the exact position of in vivo O-linked GalNAc-glycosylated serine and threonine residues from the primary sequence.

\subsection{Construction of SERK Phylogenetic Tree}

Sequences of different SERK proteins were obtained from NCBI protein database and used for phylogenetic analysis on Phylogeny.fr online platform [42] (http://www.phylogeny.fr/). MUSCLE 3.7 was used for multiple sequence alignment. Gblocks $0.91 \mathrm{~b}$ were used for alignment refinement to removes alignment noise. The parameters are set to their default values in Gblocks. PhyML 3.0 aLRT program with substitution model WAG were used for phylogeny prediction and TreeDyn 198.3 program were used for tree rendering.

\subsection{In Vitro Tissue Culture of Cotton}

Cotton (Gossypium hirsutum L. cv. Coker 310FR) plants [43] were grown in the cotton green house at Gautam 
Buddha University, UP at $32^{\circ} \mathrm{C}$ temperature and $16: 8 \mathrm{hr}$ day/night lengths. Seeds were surface sterilized using protocol of [44] and germinated on half-strength MS medium (Table 1). The cotyledonary explants from 7-dayold seedlings were used for in vitro tissue culture at $28^{\circ} \mathrm{C} \pm 2^{\circ} \mathrm{C}, 12: 12 \mathrm{hr}$ light/dark combination. The explants were incubated on different media compositions (Table 1), for the emergence of embryogenic calli. In the present study, all calli from different developmental stages were harvested at least in three biological replicates.

\subsection{Analyses of Intrinsic Disordered Region}

Intrinsically unstructured/disordered pattern in the protein sequence of AtSERK1 (highly significant for SE) in comparison to AtSERK4 (non-significant for SE) along with MtSERK1 (highly significant for SE) for validation purpose were predicted using IUPred online platform (www.iupred.enzim.hu). Protein sequences were obtained from NCBI protein database and directly submitted in IUPred in FASTA format to get the result. Unstructured/ disordered regions of protein predicted were based on estimated energy content [45]. Further, to analyse protein binding pattern with other protein in the disordered region online tool ANCHOR [46].

\subsection{Prediction of Promoter Regions for Trans-Factor Binding Sites}

AtSERK1 and AtSERK2 promoter sequences were obtained from [47]. Promoter sequences were directly submitted to plant promoter analysis navigator online platform (http://PlantPAN.mbc.nctu.edu.tw) and selected the command for transcription factor binding site analysis. For MtSERK1 promoter analysis the promoter sequences (accession EU499307) were obtained from National Center for Biotechnology Information (NCBI) database and was also analysed with Plant PAN platform using same parameter of analysis.

\section{Results and Discussion}

\subsection{Structure of SERK Proteins}

The detailed sequence analysis of SERK and SERK-like proteins was performed using different in silico tools. Studied SERK and SERK-like proteins comprised of signal peptide, leucine zipper, leucine rich repeats, Ser-Pro rich region, transmembrane domain, kinase domain and C-terminal region, however selective specific alterations were observed in the SERK proteins than SERK-like proteins. This might be important for confirmation of the precise role of SERK proteins in the acquisition of embryogenic potential in a somatic cell.

\section{Transmembrane topology}

The signalling molecules such as SERK proteins may reflect the signature of evolutionary patterns of transmembrane proteins which evolved exclusively for their role in SE. To validate this assumption, transmembrane topology was performed using Phobius online server for SERK proteins including AtSERK1, MtSERK1, StSERK1, GhSERK1 and CuSERK1. This platform was also used to understand transmembrane topology on the SERK-like proteins (earlier reported to be non-significant for SE including AtSERK4, AtSERK5, GhSERK2 and GhSERK3). Prediction results showed conserved length of cytoplasmic domain of 362 amino acid across species for SERK whereas it varied for SERK-like and of greater length (Table 2, Supplementary Figure 1).

Table 1. Constituents of different media for cotton culture as per [65].

\begin{tabular}{ccccc}
\hline Medium & 1/2 MS & MST1 & MSOT2 & MSOT3 \\
\hline Salt (MS) & $0.5 \times$ & $1 \times$ & $1 \times$ & $1 \times$ \\
B5 Vitamins & $0.5 \times$ & $1 \times$ & $1 \times$ & Glucose (3\%) \\
Carbohydrate Source & Sucrose (2\%) & Glucose $(3 \%)$ & Glucose (3\%) & - \\
Phytohormones & - & $2,4-\mathrm{D}(100 \mu \mathrm{g} / \mathrm{l})$ & - & Phytagel $(0.2 \%)$ \\
Gelling Agents & Agar $(0.7 \%)$ & Phytagel $(0.2 \%)$ & Phytagel $(0.2 \%)$ & 5.80 \\
\hline
\end{tabular}


Table 2. Comparison of different structural components of SERKs and SERK-like proteins from different species highlighting differential number of amino acids in the trans-membrane region of SERK proteins than SERK-like proteins.

\begin{tabular}{ccccccccc}
\hline Proteins & Plant Species & $\begin{array}{c}\text { Signal } \\
\text { Peptide }\end{array}$ & N-Region & H-Region & C-Region & $\begin{array}{c}\text { Non Cytoplasmic } \\
\text { Region }\end{array}$ & $\begin{array}{c}\text { Transmembrane } \\
\text { Region }\end{array}$ & $\begin{array}{c}\text { Cytoplasmic } \\
\text { Region }\end{array}$ \\
& AtSERK1 & $1-26$ & $1-5$ & $6-16$ & $17-26$ & $27-233$ & $234-262$ & $263-625=362 \mathrm{aa}$ \\
& MtSERK1 & $1-28$ & $1-6$ & $7-20$ & $21-28$ & $29-240$ & $241-264$ & $265-627=362 \mathrm{aa}$ \\
SERK & StSERK1 & $1-30$ & $1-8$ & $9-22$ & $23-30$ & $31-242$ & $243-266$ & $267-629=362 \mathrm{aa}$ \\
& GhSERK1 & $1-32$ & $1-9$ & $10-20$ & $21-32$ & $33-240$ & $241-264$ & $265-627=362 \mathrm{aa}$ \\
& CuSERK1 & $1-22$ & $1-4$ & $5-14$ & $15-22$ & $23-234$ & $235-258$ & $259-621=362 \mathrm{aa}$ \\
& AtSERLK4 & $1-33$ & $1-9$ & $10-21$ & $22-33$ & $34-229$ & $230-255$ & $256-620=364 \mathrm{aa}$ \\
PERK-Like & AtSERLK5 & $1-24$ & $1-7$ & $8-16$ & $17-24$ & $25-215$ & $216-236$ & $237-601=364 \mathrm{aa}$ \\
& GhSERLK2 & $1-32$ & $1-8$ & $9-20$ & $21-32$ & $33-227$ & $228-251$ & $252-620=368 \mathrm{aa}$ \\
& GhSERLK3 & $1-32$ & $1-8$ & $9-20$ & $21-32$ & $33-227$ & $228-251$ & $252-620=368 \mathrm{aa}$ \\
\hline
\end{tabular}

Interestingly, investigated SERK proteins contained smaller cytoplasmic domain of 362 amino acids (aa) than to SERK-like proteins comprising upto 368 aa. Consistency in the length of cytoplaasmic domain of SERK proteins and SERK-like protein may be accounted for their diverse functional evolution across species.

\section{Short linear motifs}

Short linear motifs (SLiMs) are the short amino acid chains earlier reported to be important in mediating the regulatory functionality in the cell, mainly in cell signalling [48]. SLiMs bind to the target in conditional, transient and tunable manner so that it may regulate many cellular functionalities. Genesis of novel SLiMs in the cell is easy due to least number of residues in the motifs responsible for their specificity. As a result SLiMs perform as driver of different gene network evolution by facilitating unique interface for interaction of proteins. The plasticity in SLiMs make it amenable for convergent evolution of many genes for a particular function in cellular pathways [49]. The affinity and specificity determining residues are usually encoded between 3 and 11 contiguous amino acids [50].

Since the acquisition of SE is directly dependent upon the induction of cellular signalling mainly through SERK proteins, it becomes essential to explore the possibilities for the precise role of SLiMs in this mechanism. Therefore, SERK gene sequences of Arabidopsis (AtSERK1) and Medicago (MtSERK1) reported beforehand as robust biomarkers of SE [25] [47], were compared to the SERK-like sequence of Arabidopsis (AtSERK4) using ELM database of SLiMs [41]. Three significantly different linear motifs were observed exclusively in the SERK proteins viz. LIG_BRCT_BRCA1; DOC_CYCLIN_1 and LIG_EVH1_2 (Figure 1). The number of these domains was much higher in SERK proteins than SERK-like proteins ranging the difference from 2 - 4 motifs per region. Surprisingly, in spite of such an important role in cellular regulatory network the information on linear motifs is still inadequate. However, presence of SLiMs exclusively in SERK proteins than SERK-like proteins across species highlighted their direct co-relation with the acquisition of SE. The experimental validation of SLiMs for their direct correlation with SE would further enhance our understanding to establish their precise role through functional evolution.

\section{O-GalNAc (mucin type) glycosylation sites}

The process of an addition of a sugar chain to a protein is called glycosylation. Emerging genetic studies have revealed the function of a subset of glycosyltransferases gene family responsible for the formation of mucintype-O-glycans essential for normal plant development. Mucin-type O-glycosylation, consisting of glycans attached via $O$-linked $N$-acetylgalactosamine (GalNAc) to serine and theronine residues, is one of the most abundant forms of protein glycosylation [51]. When SERK protein sequences AtSERK1 and MtSERK1 were compared with SERK-like protein sequence of AtSERK4, more O-glycosylation sites were observed in AtSERK4 protein sequence than AtSERK1 and MtSERK1 mainly between 200 - 300 aa (Figures 2(C)). This highlights the negative co-relation of O-GalNAc with SE. This fact has already been experimentally validated in case of the high SE inducer arabinogalactan proteins, having least pretentious protein segment due to high glycosylation [52]. Though there are no data available for the direct role of O-glycosylation in the intricate mechanism 


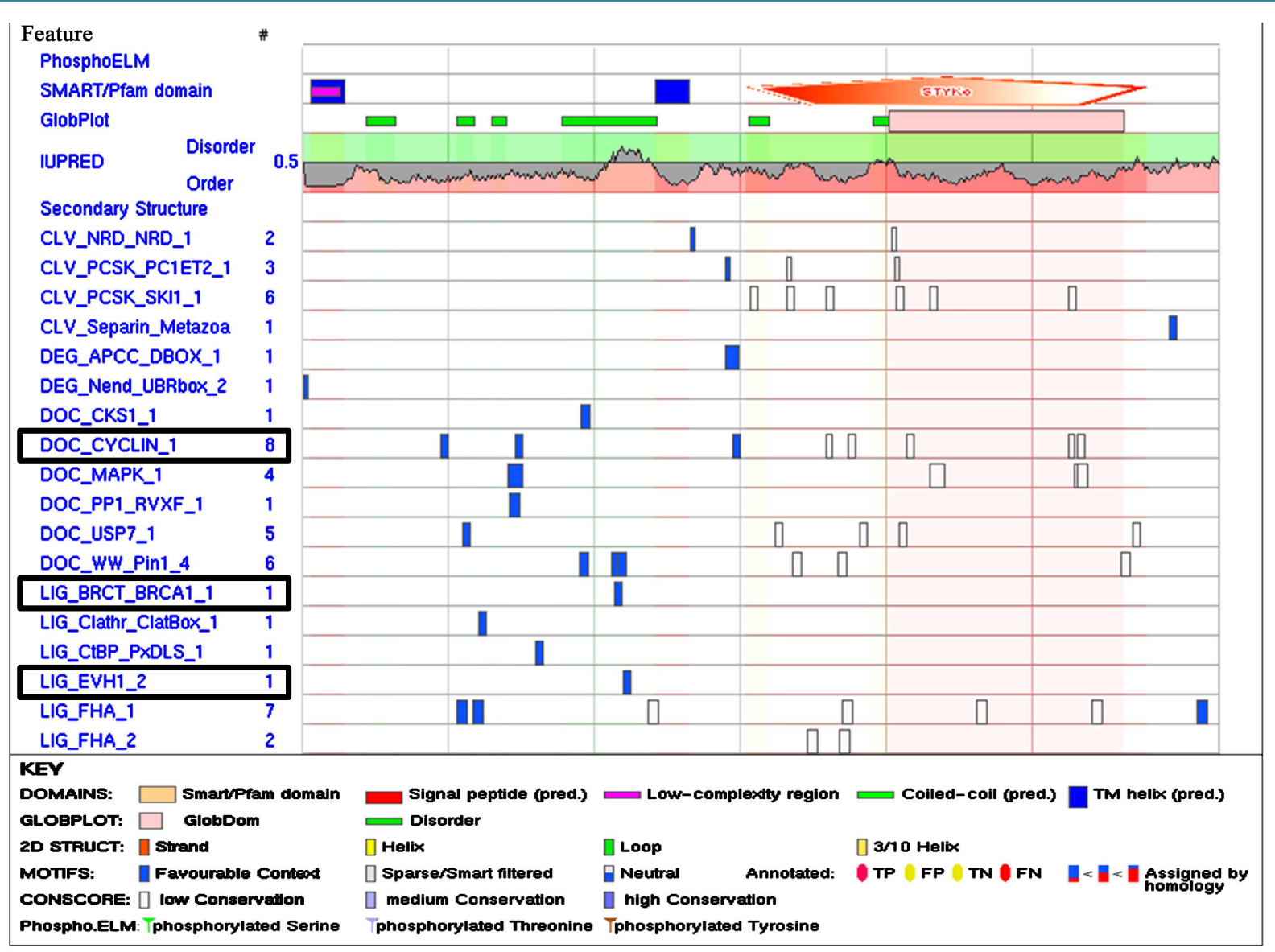

Figure 1. SLiMs of a typical SERK sequence from MtSERK1. Three significantly different linear motifs remain present exclusively in the SERK proteins viz. DOC_CYCLIN_1; LIG_BRCT_BRCA1_1 and LIG_EVH1_2, as highlighted with the box.

of SE, experimental validation of these important differences between SERK and SERK-like proteins would enhance our understanding to the key genes regulating different pathways in SE.

\subsection{Evolution of SERK and SERK-Like Proteins}

Members of receptor kinase protein family play diverse roles in different biological systems. Besides SE, they contribute in BR signalling pathway, cell death control pathway, disease resistance pathway, microsporogenesis and apomixes (Table 3). Protein sequences of different SERK and SERK-like proteins of monocots Zea mays, Triticum aestivum, Cocos nucifera, Ananas comosus; and eudicots Daccus carota, Solanum tuberosum, Arabidopsis thaliana, Medicago trancatula, Citrus spp., Gossypium hirsutum, Cyclamen persicum, Carica papaya, and Rosa canina were used for phylogenetic analysis. These SERK and SERK-like proteins have previously been characterized for their specific functions [31] [53]. On the basis of sequence alignment result, the amino acid sequence of dicot and monocot species showed high homologous regions mainly in the receptor kinase region, as also shown previously [18]. However, maximum differences were observed in their peptide signal domains probably due to different functions. Further using the alignment results, a phylogenetic tree was constructed establishing the evolutionary relationship among all studied SERK and SERK-like protein sequences (Figure 3). Phylogenetic analysis showed that plant SERK and SERK-like genes grouped into three different groups harboring monocots, conifers and eudicots, respectively (Figure 3). Presence of SERK proteins in angiosperm to gymnosperm indicates that evolution of SERKs occurred before the divergence of monocots and eudicots, around 150 MY ago. Phylogenetic evidence also supported the retention of multiple SERK paralogs following both ancient and more recent duplication events. It is thus hypothesized that SERK protein variants are evolved under Darwinian selection through partitioning of function between homeologs of the co-resident genomes of allopolyploids. Therefore, orthology of SERK gene family is inversely proportional to their function. 
Table 3. List of selective SERK and SERK-like reported genes from different plant species with their characterized function.

\begin{tabular}{|c|c|c|c|c|c|}
\hline Name of Gene & Species & Gene Type & Characterized Function & References & Remarks \\
\hline AtSERK1 & Arabidopsis & SERK & Somatic embryogenesis & [47] & $\begin{array}{l}\text { Total } 5 \text { members in } \\
\text { SERK gene family } \\
\text { of Arabidopsis }\end{array}$ \\
\hline AtSERK2 & Arabidopsis & SERK-like & $\begin{array}{l}\text { Microsporgenesis, BR signalling } \\
\text { pathway, cell death control pathway }\end{array}$ & [47] & \\
\hline $\begin{array}{l}\text { AtSERK3 } \\
\text { (BAK1) }\end{array}$ & Arabidopsis & SERK-like & $\begin{array}{l}\text { BR signalling pathway, cell death control } \\
\text { pathway, disease resistance pathway }\end{array}$ & [66] & \\
\hline $\begin{array}{l}\text { AtSERK4 } \\
\text { (BKK1) }\end{array}$ & Arabidopsis & SERK-like & $\begin{array}{l}\text { BR signalling pathway, } \\
\text { cell death control pathway }\end{array}$ & [66] & \\
\hline AtSERK5 & Arabidopsis & SERK-like & & [67] & $\begin{array}{l}\text { SERK5 might not be } \\
\text { functional due to a natural } \\
\text { point mutation at a highly } \\
\text { conserved "RD" motif }\end{array}$ \\
\hline OsSERK1 & Oryza sativa & SERK-like & $\begin{array}{l}\text { Defence signal transduction, } \\
\text { somatic embryogenesis }\end{array}$ & [68] & \\
\hline MtSERK1 & $\begin{array}{l}\text { Medicago } \\
\text { truncatula }\end{array}$ & SERK & Somatic embryogenesis & [69] & $\begin{array}{l}\text { A total of nine SERK or } \\
\text { SERK-like genes have been } \\
\text { identified in M. truncatula }\end{array}$ \\
\hline SERK & $\begin{array}{l}\text { Dactylis } \\
\text { glomerata, }\end{array}$ & SERK & Somatic embryogenesis & [23] & \\
\hline SERK & $\begin{array}{l}\text { Helianthus } \\
\text { annuus }\end{array}$ & SERK & Somatic embryogenesis & [24] & \\
\hline SERK & $\begin{array}{l}\text { Ocotea } \\
\text { catharinensi }\end{array}$ & SERK & Somatic embryogenesis & [70] & \\
\hline SERK & Theobroma сасао & SERK & Somatic embryogenesis & [28] & \\
\hline PpSERK & Poa pratensis & SERK & Apomixis & [71] & \\
\hline McSERK & $\begin{array}{l}\text { Momordica } \\
\text { charantia }\end{array}$ & SERK & Somatic embryogenesis & [72] & \\
\hline DcSERK & Daucus carota & SERK & Somatic embryogenesis & [18] & \\
\hline CitSERK1 & Citrus sinensis & SERK & Somatic embryogenesis & [73] & \\
\hline SERK & Citrus unshiu & SERK & Somatic embryogenesis & {$[22]$} & \\
\hline TaSERK1 & Triticum aestivum & SERK & Somatic embryogenesis & [29] & \\
\hline GmSERK1 & Glycine max & SERK & Somatic embryogenesis & [74] & $\begin{array}{l}\text { A total of } 17 \\
\text { SERK in soybean }\end{array}$ \\
\hline AaSERK1 & $\begin{array}{l}\text { Araucaria } \\
\text { angustifolia }\end{array}$ & SERK & Somatic embryogenesis & [75] & Gymnosperm \\
\hline CISERK & $\begin{array}{l}\text { Cyrtochilum } \\
\text { loxense }\end{array}$ & SERK & Somatic embryogenesis & {$[76]$} & Gymnosperm \\
\hline CnSERK & Cocos nucifera & SERK & Somatic embryogenesis & {$[21]$} & \\
\hline
\end{tabular}

In Group I of monocots, SERK and SERK-like genes of maize and wheat showed close relationship than coconut and Ananas, and clustered into a single group with an average of $69 \%$ identity. The cluster includes both SERK and SERK-like protein sequences and has been reported to be involved in SE and other roles of the SERK proteins, alone or in combination with other members. Group II is constituted with two conifers Pinus and Araucaria aligned together with high amino acid similarity. However, all studied eudicots constructed group III harboring different species of Solanum, Cyclamen and Citrus spp. along with other taxa (Figure 3). Three 


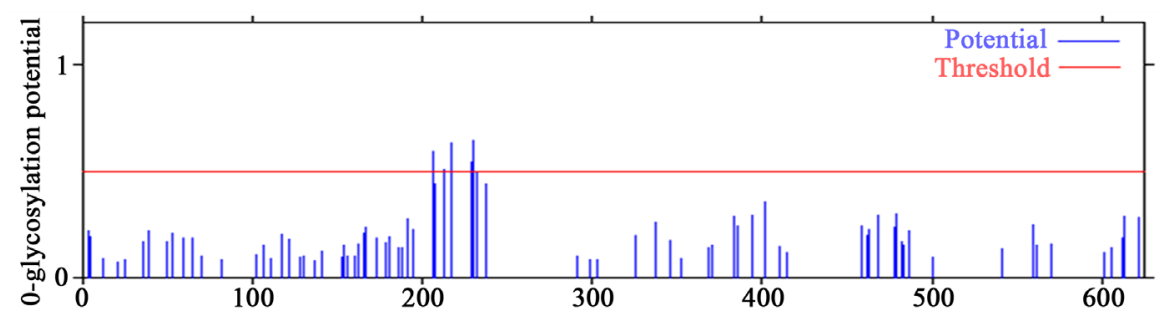

(A)

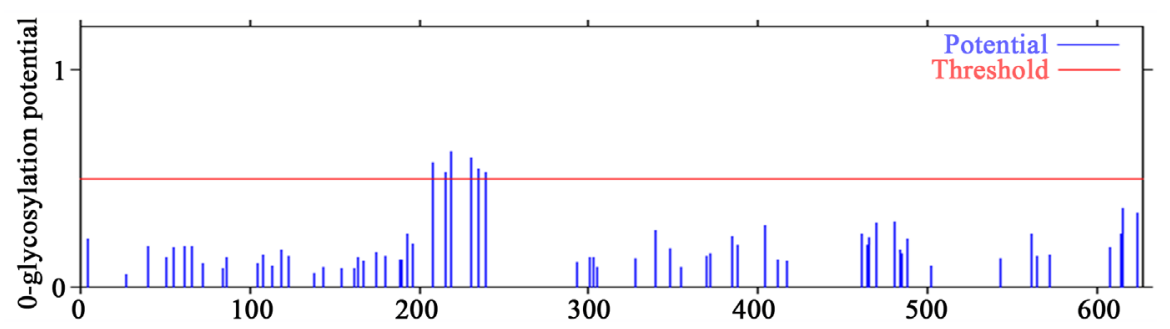

(B)

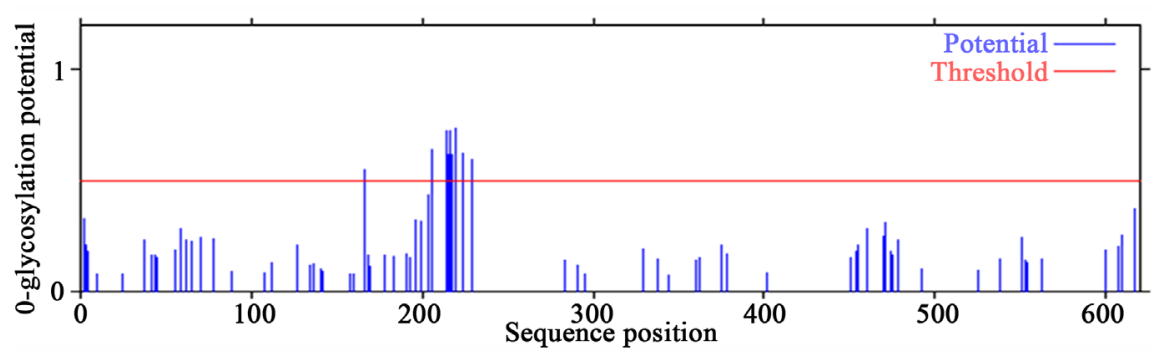

(C)

Figure 2. Prediction of O-glycosylation sites in SERK and SERK-like genes. (A) Protein sequence of AtSERK1; (B) Protein sequence of MtSERK1; (C) Protein sequence of AtSERK4.

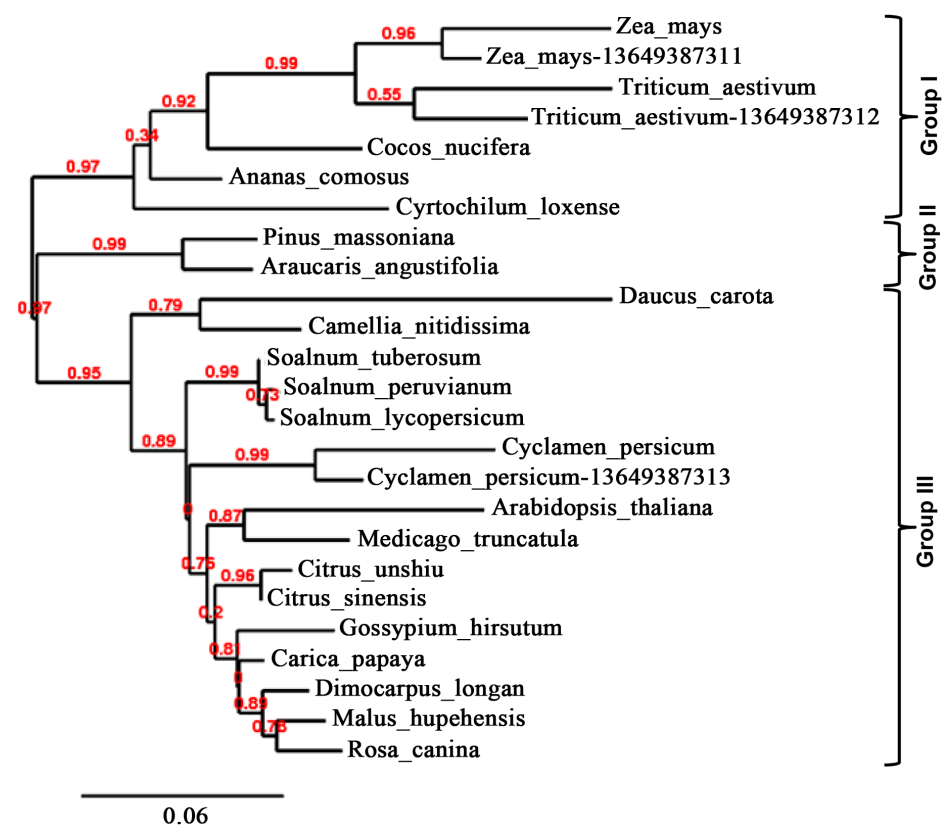

Figure 3. Phylogenetic analysis of SERK and SERK-like genes and other homologs reported earlier to have their direct role in SE and in other metabolic pathways, respectively. 
SERK protein variants from different species of genus Solanum clustered together highlighting high amino acid sequence similarity with most recent genic duplication of SERK and SERK-like genes. The Arabidopsis SERK protein has five variants of SERK and SERK-like genes involved in SE, brassinosteroid signalling pathways and male microsporogenesis, respectively [31]. This data suggest that many SE-related SERK genes are evolutionarily conserved among plant species, though not for their functional component.

Similarly, isolation and characterization of three cotton (Gossypium) homoelogous SERK and SERK-like genes with their full-length transcript sequence have been reported previously, exhibiting homology with other species SERK sequences, for example, five SERK genes from Arabidopsis [20], four genes from Helianthus annus [24], and three genes from Zea mays [20]. In our laboratory, functional characterization of cotton SERK1 (GhSERK1) in the progression of SE was performed during cotton regeneration through SE involving first, second and third phase calli (Figures 4(A)-(C)). The expression changes in cell-signaling factor GhSERK1 and its other variants were analyzed in different phase calli of a fully-regenerating line. In result, significant expression up-regulation of only GhSERK1 was observed in the embryogenic calli than non-detectable expression levels of GhSERK2 and GhSERK3 (illustrated by shaded area). This experimental evidence further supports our hypothesis of functional co-evolution of different SERK and SERK-like protein variants.

Expression comparison of SERK with SERK-like genes firmly distinguished both class of receptor kinases. The SERK-like proteins appeared to revert the growth reduction by the loss of SERK-mediated cell-signaling required during SE. This indicates that differences in SERK and SERK-like proteins' expression specificity may be true reflection of significant accordance with their physiological functions. Though these results are preliminary and further work is required to determine if SERKs fully complements under growth and stress conditions. Given the high sequence similarity among different SERK members across taxa, it could also be assumed that this class of proteins are functionally redundant, thereby masking a synergistic effect with SERK-like variants.

\subsection{Possible Role of Intrinsic Disordered Region of SERK Proteins in SE}

Intrinsically disordered proteins (IDPs) have no sole explicit tertiary structure in their native functional state due to their intrinsic flexibility. Till recently, any protein is considered for a functional property based on its tertiary structure, and based on this conjecture more than $80 \mathrm{~K}$ protein sequences have been deposited in the protein data bank so far. Interestingly, out of these nearly 1000 structures are now among the registry of unstructured or disordered chains which only convert itself into prerequisite structured forms in response to an appropriate signal/ stimuli received in the form of a protein/ligand [54]. This may however be considered as advantageous on functional basis as the IDPs undergo induced disordered-to-ordered transition in response to the pertinent signals [55]. Thus it is apparent that structural disordered regions of proteins have a strong potential to define and redefine the cellular signalling pathways during cellular development. Most recently it has shown that such disor-

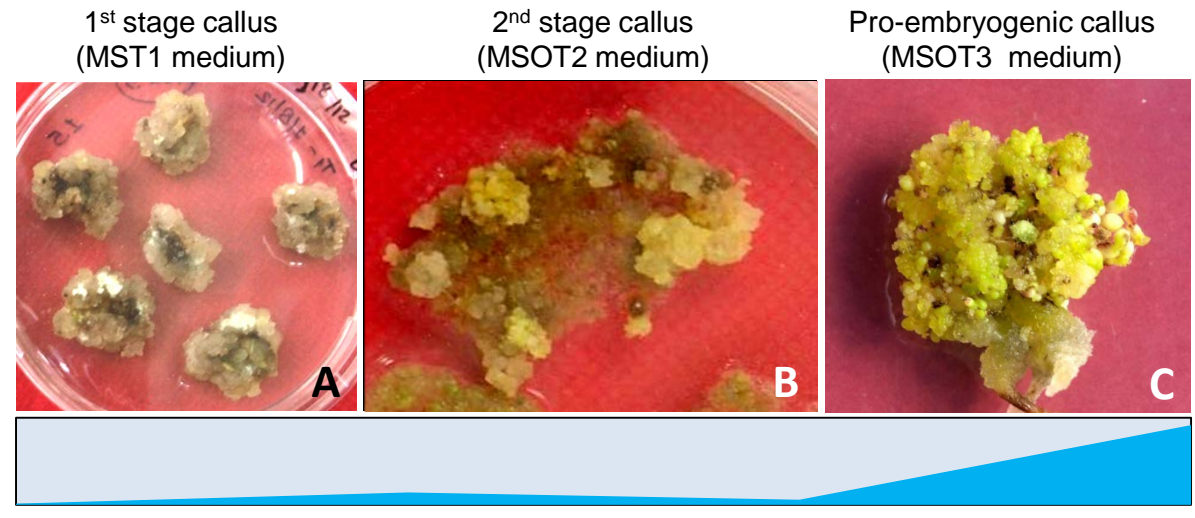

Figure 4. Regeneration of cotton (Gossypium hirsutum L. cv. Coker 310) through somatic embryogenesis [65]. (A) Cotyledonary explants with yellowish-friable callus; (B) Yellowish-white granular embryogenic callus after second sub-culture; (C) Embryogenic callus after 15 days of incubation. Relative quantification of GhSERK transcripts in the corresponding stages of regeneration is shown. Normalized values are plotted from different tissues analysed including three stages of callus formation. Significant expression up-regulation of GhSERK1 observed in the embryogenic calli on MSOT3 medium is illustrated with shaded area. 
dered regions are very important for the function of a protein and helps in protein folding within very short timeframe only in response to an appropriate signal [56].

Previously in our laboratory, it has been shown that application of diverse stress conditions in vitro induce SE among plant species. For example, micronutrient boron-mediated stress increased endogenous auxin level that in turn up-regulated the selected variant of signalling molecule SERK in SE-competent somatic cells [15]. Since members of SERK gene family are functionally diverged, specific pattern of intrinsic disordered regions of SERK protein might be important for induced folding and its activation in response to the applied stress condition. Hence, it is subjected to further investigation identifying the actual ligands and partner protein which induce SERK molecules for proper folding in SE.

To validate this conjecture, SERK protein sequences of Arabidopsis (AtSERK1) and Medicago (MtSERK1) reported beforehand as robust biomarkers of SE [25] [47], were compared to the SERK-like sequence of Arabidopsis (AtSERK4) for the elements of intrinsic disorderdness using IUPred platform. In result, patterns of intrinsic disordered regions beyond the threshold are significant and comparable between SERK proteins of AtSERK1 and MtSERK1 than SERK-like protein of AtSERK4 (Figure 5). Further, to confirm the disordered regions' characteristics, prediction of binding region of other proteins with disordered regions was also performed. It was observed that both AtSERK1 and MtSERK1 have no binding regions available (Figure 5(A) and Figure 5(B)) whereas AtSERK4 has one disordered binding region from amino acid 193 to 200 (Figure 5(C)) [45] [46].

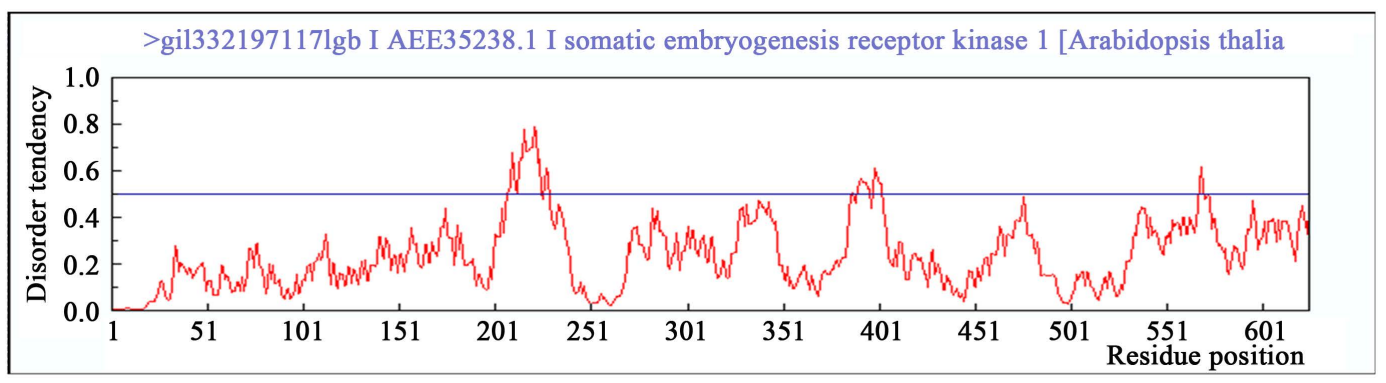

(A)

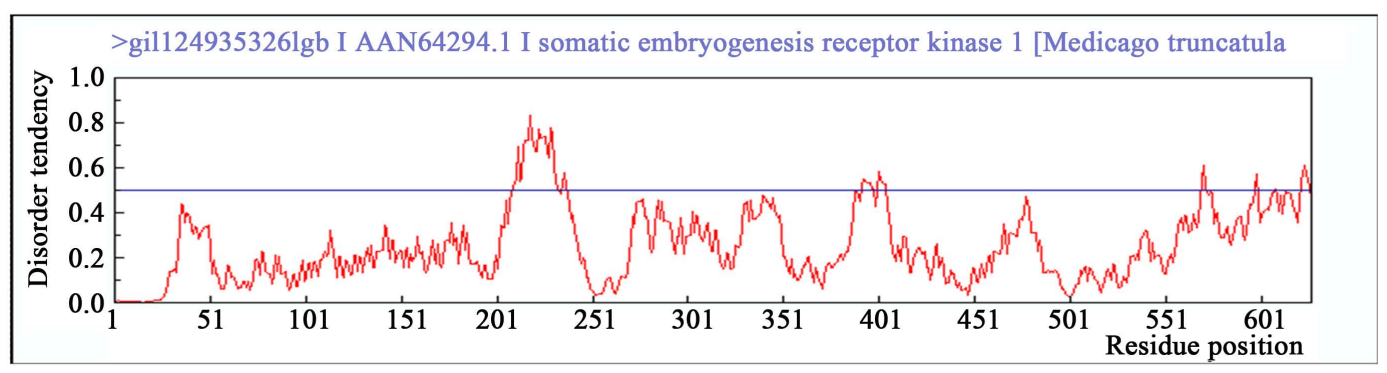

(B)

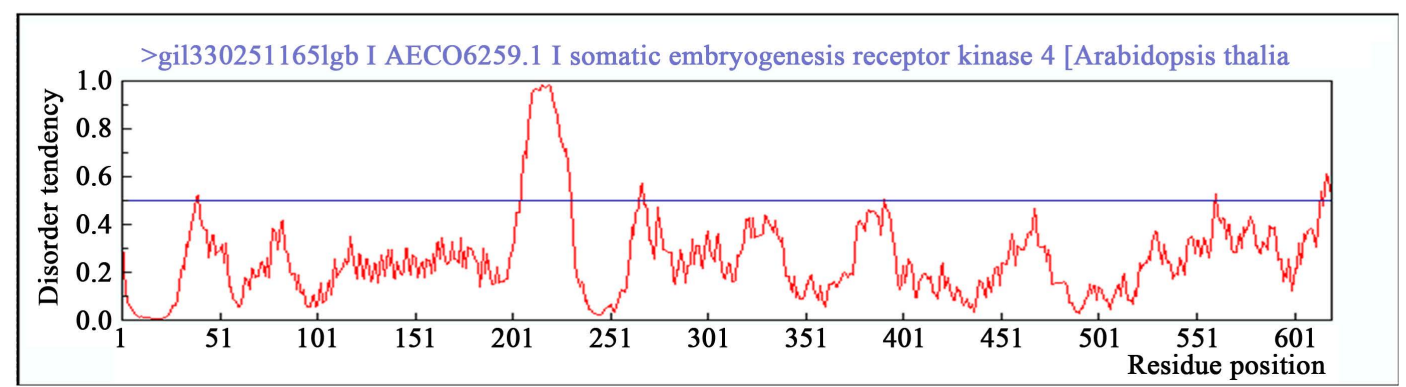

(C)

Figure 5. Prediction of intrinsic disordered regions in SERK and SERK-like genes. (A) SERK protein sequence of Arabidopsis SERK1 (AtSERK1) reported earlier for its direct role in SE; (B) SERK protein sequence of $M e$ dicago SERK1 (MtSERK1) reported earlier for its direct role in SE; (C) SERK protein sequence of Arabidopsis SERK4 (AtSERK4) known for having no role in SE. Any incisive peak touching or crossing the threshold (0.5) disorder tendency was considered to be significant disordered region. 
The disordered regions identified in AtSERK1 and MtSERK1 proteins may thus be assumed to perceive external stress-induced signals those in result mediate quick protein folding bringing the property for switching-on the cellular signals essential for the acquisition of SE. However, it would be fascinating to search the fine balance between type and intensity of stress that is required for the induction of proper folding of disordered regions of SERK protein and its contribution towards SE acquisition. Also, refolding of these disordered regions in SERK protein in response of stress may have affected more indigenous pathways which compelled somatic-toembryo transition. Therefore, probably such flexible regions are one of the key regions of SERK proteins intended to trigger SE in plants.

\subsection{Structural Evolution of SE-Specific Promoter Regions of SERK Genes}

The endogenous auxin-mediated induction of cell-signalling through up-regulated SERK genes has earlier been revealed at the onset of in vitro SE [15]. However, SERK-like proteins have their defined role in distinct metabolic pathways than in SE. The AtSERK1 protein has been reported for its high expression in the embryogenic callus of Arabidopsis than AtSERK2 protein and considered as an efficient biomarker of SE [19] [31] [57]. To understand the spatial expression of such signalling genes required for SE, the regulatory sequences of two different genes of Arabidopsis that are SERK (AtSERK1) and SERK-like genes (AtSERK2) were analyzed. Significant differences in the transcription factor binding sites were observed within the promoter regions of SERK (AtSERK1) and SERK-like (AtSERK2) genes. Interestingly, in the promoter region of AtSERK1 gene, AINTEGUMENTA (ANT) transcription factor binding site is prominently accessible in the promoter region than in the upstream region of AtSERK2 gene.

AINTEGUMENTA is an AP2-like ethylene responsive transcription factor, a family of proteins involved in ethylene signal transduction recognizing and binding to the DNA consensus sequence 5'-CAC[AG]N[AT] TNCCNANG-3' [58]-[61]. The trans-factor ANT has been reported for its important role in the cellular fate deciding processes throughout the development of ovule and female gametophyte; and even upto embryogenesis. Previously, higher expression levels of ANT have been detected in the developing and mature flower tissues [59] [61]. The ANT factor contains two AP2 domains homologous with the DNA binding domain of ethylene response element binding proteins, demonstrated earlier for their utility in SE process [62]. As shown previously [60], ANT plays an important role in the maintenance of proliferative cell state during embryogenesis and consequently in organogenesis. Further, primordia are initiated at the sites of auxin accumulation within the peripheral zone of embryo developmental stages and PIN proteins play important role in the supply of auxin [63] [64]. It is thus clear that ANT transcription factors are regulated by auxin gradient suggested for auxin-mediated regulation of ANT transcription factor in SE. The ANT is part of a complex and robust molecular system that coordinates patterning signals and cellular proliferation through embryo development [58]. This data indeed provide support for the structural changes in the regulatory sequence of AtSERK1 gene evolved exclusively for its spatial expression during SE, than the regulatory sequences of AtSERK2 gene.

However, this is still a concern whether such evolutionary changes are species-specific or global? To confirm this hypothesis, regulatory sequence of SERK variant of Medicago truncatula (MtSERK1) reported earlier as significant biomarker of SE [25], was analysed and compared with AtSERKs regulatory sequences. Since MtSERK1 is important for SE, any structural change evolved in the regulatory sequences as a prerequisite to SE would support the hypothesis of global evolution of SE-specific regions or vice-versa. In result, similar to the regulatory region of AtSERK1 gene, an ANT binding site was also present in the regulatory sequence of MtSERK1 gene which further validated the evolution of ANT transcription factors towards their precise role in the acquisition of SE across species. Regulation of SERK genes through ANT transcription factor binding and its upstream regulation by hormonal balance is a new approach towards revealing the molecular mechanism for SE acquisition.

\section{Conclusion}

The current study implicates the structural evolution of receptor kinases involved in the intricate process of SE, enhancing our understanding for the SERK-mediated cell-signalling during SE. We provide evidences for the evolution of precise structural components in the receptor kinases and their regulatory sequences through a comparison of SERK and SERK-like proteins, reported earlier for their direct role in embryogenic transitions and other metabolic pathways, respectively. In general, presence of SERKs across angiosperm to gymnosperm 
highlights the evolution of such proteins much before in the plant kingdom for the enhancement of occurrence and magnitude of embryogenesis through fine-tuning of cell-siganling genes. Remarkably, intrinsic disordered regions known for their role in protein folding in response to a stress signal, various SE-related components on the N-terminal part of the proteins along with SE-specific trans-factor binding sites are diagnosed as having become enhanced system-wide exclusively in SERK proteins. An exciting prospect for future work will be to dissect these structural modifications and their responsible constituents for their precise role in the complex mechanism of SE.

\section{Acknowledgements}

The authors are thankful to the Council of Scientific and Industrial Research (CSIR), and the Department of Biotechnology (DBT), Government of India, for providing the financial support to carry out cotton research work in the laboratory.

\section{References}

[1] Gray, D., Compton, M., Harrell, R. and Cantliffe, D. (1995) Somatic Embryogenesis and the Technology of Synthetic Seed. In: Bajaj, Y., Ed., Somatic Embryogenesis and Synthetic Seed I. Biotechnology in Agriculture and Forestry, Vol. 30, Springer-Verlag, Berlin, 126-151. http://dx.doi.org/10.1007/978-3-662-03091-2_9

[2] Toonen, M. and De Vries, S. (1996) Initiation of Somatic Embryos from Single Cells. In: Wang T. and Cuming, A., Eds., Embryogenesis: The Generation of a Plant, Bios Scientific Publishers, Oxford, 173-189.

[3] Kawahara, R. and Komamine, A. (1995) Molecular Basis of Somatic Embryogenesis. In: Bajaj, Y., Ed., Biotechnology in Agriculture and Forestry, Somatic Embryogenesis and Synthetic Seed, Vol. 30, Springer-Verlag, Berlin, 30-40. http://dx.doi.org/10.1007/978-3-662-03091-2 3

[4] Arnold, S., Sabala, I., Bozhkov, P., Dyachok, J. and Filonova, L. (2002) Developmental Pathways of Somatic Embryogenesis. Plant Cell, Tissue and Organ Culture, 69, 233-249. http://dx.doi.org/10.1023/A:1015673200621

[5] Jimenez, V. (2001) Regulation of in Vitro Somatic Embryogenesis with Emphasis on to the Role of Endogenous Hormones. Revista Brasileira De Fisiologia Vegetal, 13, 196-223. http://dx.doi.org/10.1590/S0103-31312001000200008

[6] Chugh, A. and Khurana, P. (2002) Gene Expression during Somatic Embryogenesis-Recent Advances. Current Science, 86, 715-730.

[7] Zavattieri, M., Frederico, A., Lima, M., Sabino, R. and Arnholdt-Schmitt, B. (2010) Induction of Somatic Embryogenesis as an Example of Stress-Related Plant Reactions. Electronic Journal of Biotechnology, 13. http://dx.doi.org/10.2225/vol13-issue1-fulltext-4

[8] Dudits, D., Bogre, L. and Gyorgyey, J. (1991) Molecular and Cellular Approaches to the Analysis of Plant Embryo Development from Somatic Cells in Vitro. Journal of Cell Science, 99, 473-482.

[9] Dudits, D., Györgyey, J., Bögre, L. and Bakó, L. (1995) Molecular Biology of Somatic Embryogenesis. In: Thorpe, T., Ed., In Vitro Embryogenesis in Plants, Kluwer Academic Publishers, Dordrecht, 267-308. http://dx.doi.org/10.1007/978-94-011-0485-2_8

[10] Faure, O., Dewitte, W., Nougarède, A. and Van Onckelen, H. (1998) Precociously Germinating Somatic Embryos of Vitis vinifera Have Lower ABA and IAA Levels than Their Germinating Zygotic Counterparts. Physiologia Plantarum, 102, 591-595. http://dx.doi.org/10.1034/j.1399-3054.1998.1020414.X

[11] Ikeda-Iwai, M., Umehara, M., Satoh, S. and Kamada, H. (2003) Stress-Induced Somatic Embryogenesis in Vegetative Tissues of Arabidopsis thaliana. The Plant Journal, 34, 107-114. http://dx.doi.org/10.1046/j.1365-313X.2003.01702.x

[12] Kamada, H., Kobayashi, K., Kiyosue, T. and Harada, H. (1989) Stress Induced Somatic Embryogenesis in Carrot and Its Application to Synthetic Seed Production. In Vitro Cellular \& Developmental Biology, 25, 1163-1166. http://dx.doi.org/10.1007/BF02621268

[13] Davletova, S., Meszaros, T., Mészáros, P., Oberschal, A., Török, K., Magyar, Z., Dudits, D. and Deák, M. (2001) Auxin and Heat Shock Activation of a Novel Member of the Calmodulin Like Domain Protein Kinase Gene Family in Cultured Alfalfa Cells. Journal of Experimental Botany, 52, 215-221. http://dx.doi.org/10.1093/jexbot/52.355.215

[14] Györgyey, J., Gartner, A., Magyar, Z., Hirt, H., Heberle-Bors, E. and Dudits, D. (1991) Alfalfa Heat Shock Genes Are Differentially Expressed during Somatic Embryogenesis. Plant Molecular Biology, 16, 999-1007. http://dx.doi.org/10.1007/BF00016072

[15] Pandey, D.K., Singh, A. and Chaudhary, B. (2012) Boron-Mediated Plant Somatic Embryogenesis: A Provocative Model. Journal of Botany, 2012, Article ID: 375829.

[16] Fujimura, T. and Komamine, A. (1980) Mode of Action of 2,4-D and Zeatin on Somatic Embryogenesis in a Carrot 
Cell Suspension Culture. Zeitschrift für Pflanzenphysiologie, 99, 1-8. http://dx.doi.org/10.1016/S0044-328X(80)80106-1

[17] Saze, H., Scheid, O. and Paszkowski, J. (2003) Maintenance of CpG Methylation Is Essential for Epigenetic Inheritance during Plant Gametogenesis. Nature Genetics, 34, 65-69. http://dx.doi.org/10.1038/ng1138

[18] Schmidt, E., Guzzo, F., Toonen, M. and de Vries, S. (1997) A Leucine-Rich Repeat Containing Receptor-Like Kinase marks Somatic Plant Cells Competent to Form Embryos. Development, 124, 2049-2062.

[19] Hecht, V., Vielle-Calzada, J., Hartog, M., Schmidt, E., Boutilier, K., Grossniklaus, U. and de Vries, S. (2001) The Arabidopsis Somatic Embryogenesis Receptor Kinase1 Gene Is Expressed in Developing Ovules and Embryos and Enhances Embryogenic Competence in Culture. Plant Physiology, 127, 803-816. http://dx.doi.org/10.1104/pp.010324

[20] Baudino, S., Brettschneider, R., Hecht, V., Dresselhaus, T., Lörz, H., Dumas, C. and Rogowsky, P. (2001) Molecular Characterization of Novel Maize LRR Receptor-Like Kinases, Which Belong to the SERK Family. Planta, 213, 1-10. http://dx.doi.org/10.1007/s004250000471

[21] Pérez-Núñez, M., Souza, R., Sáenz, L., Chan, J., Zúñiga-Aguilar, J. and Oropeza, C. (2009) Detection of a SERK-Like Gene in Coconut in Vitro Cultures and Analysis of Its Expression during the Formation of Embryogenic Callus and Somatic Embryos. Plant Cell Reports, 28, 11-19. http://dx.doi.org/10.1007/s00299-008-0616-8

[22] Shimada, T., Hirabayashi, T., Fujii, H., Kita, M. and Omura, M. (2005) Isolation and Characterization of the Somatic Embryogenesis Receptor-Like Kinase Gene Homologue (CitSERK) from Cirus unshiu. Marc. Scientia Horticulturae, 103, 233-238. http://dx.doi.org/10.1016/j.scienta.2004.07.005

[23] Somleva, M., Schmidt, E. and de Vries, S. (2000) Embryogenic Cells in Dactylis glomerata L. (Poaceae) Explants Identified by Cell Tracking and by SERK Expression. Plant Cell Reports, 19, 718-726. http://dx.doi.org/10.1007/s002999900169

[24] Thomas, C., Meyer, D., Himber, C. and Steinmetz, A. (2004) Spatial Expression of a Sunflower SERK Gene during Induction of Somatic Embryogenesis and Shoot Organogenesis. Plant Physiology and Biochemistry, 42, 35-42. http://dx.doi.org/10.1016/j.plaphy.2003.10.008

[25] Nolan, K., Irwanto, R.R. and Rose, R.J. (2003) Auxin Up-Regulates MtSERK1 Expression in Both Medicago truncatula Root-Forming and Embryogenic Cultures. Plant Physiology, 133, 218-230. http://dx.doi.org/10.1104/pp.103.020917

[26] Hu, H., Xiong, L. and Yang, Y. (2005) Rice SERK1 Gene Positively Regulates Somatic Embryogenesis of Cultured Cell and Host Defense Response against Fungal Infection. Planta, 222, 107-117. http://dx.doi.org/10.1007/s00425-005-1534-4

[27] Sharma, S., Millam, S., Hein, I. and Bryan, G. (2008) Cloning and Molecular Characterisation of a Potato SERK Gene Transcriptionally Induced during Initiation of Somatic Embryogenesis. Planta, 228, 319-330. http://dx.doi.org/10.1007/s00425-008-0739-8

[28] Santos, M., Romano, E., Yotoko, K., Tinoco, M., Dias, B. and Argao, F. (2005) Characterisation of the Cacao Somatic Embryogenesis Receptor-Like Kinase (SERK) Gene Expressed during Somatic Embryogenesis. Plant Science, 168, 723-729. http://dx.doi.org/10.1016/j.plantsci.2004.10.004

[29] Singla, B., Khurana, J. and Khurana, P. (2008) Charecterization of Three Somatic Embryogenesis Receptor Kinase Genes from Wheat, Triticum aestivum. Plant Cell Reports, 27, 833-843. http://dx.doi.org/10.1007/s00299-008-0505-1

[30] Maillot, P., Lebel, S., Schellenbaum, P., Jacques, A. and Walter, B. (2009) Differential Regulation of SERK, LEC1Like and Pathogenesis-Related Genes during Indirect Secondary Somatic Embryogenesis in Grapevine. Plant Physiology and Biochemistry, 47, 743-752. http://dx.doi.org/10.1016/j.plaphy.2009.03.016

[31] Albrecht, C., Russinova, E., Kemmerling, B., Kwaaitaal, M. and de Vries, S. (2008) Arabidopsis Somatic Embryogenesis Receptor Kinase Protein Serves Brassinosteroid-Dependent and Independent Signalling Pathway. Plant Physiology, 148, 611-619. http://dx.doi.org/10.1104/pp.108.123216

[32] Braybrook, S., Stone, S., Park, S., Bui, A., Le, B., Fischer, R., Goldberg, R. and Harada, J. (2006) Genes Directly Regulated by LEAFY COTYLEDON2 Provide Insight into the Control of Embryo Maturation and Somatic Embryogenesis. Proceedings of the National Academy of Sciences of the United States of America, 103, 3468-3473. http://dx.doi.org/10.1073/pnas.0511331103

[33] Casson, S., Spencer, M., Walker, K. and Lindsey, K. (2005) Laser Capture Microdissection for the Analysis of Gene Expression during Embryogenesis of Arabidopsis. The Plant Journal, 42, 111-123. http://dx.doi.org/10.1111/j.1365-313X.2005.02355.x

[34] Heidmann, I., Lambalk, J., Joosen, R., Angenent, G., Custers, J. and Boutilier, K. (2006) Expression of BABY BOOM Induces Somatic Embryogenesis in Tobacco. International Conference “Haploids in Higher Plants III”, Vienna, 52, 12-15.

[35] Ikeda, M., Umehara, M. and Kamada, H. (2006) Embryogenesis-Related Genes; Its Expression and Roles during So- 
matic and Zygotic Embryogenesis in Carrot and Arabidopsis. Plant Biotechnology, 23, 153-161. http://dx.doi.org/10.5511/plantbiotechnology.23.153

[36] Nolan, K.E., Kurdyukov, S. and Rose, R.J. (2009) Expression of the SOMATIC EMBRYOGENESIS RECEPTORLIKE KINASE1 (SERK1) Gene Is Associated with Developmental Change in the Life Cycle of the Model Legume Medicago truncatula. Journal of Experimental Botany, 60, 1759-1771. http://dx.doi.org/10.1093/jxb/erp046

[37] Passarinho, P., Ketelaar, T., Xing, M., Van Arkel, J., Maliepaard, C., Hendriks, M., Joosen, R., Lammers, M., Herdies, L., Boer, B., Van Der Geest, L. and Boutilier, K. (2008) BABY BOOM Target Genes Provide Diverse Entry Points into Cell Proliferation and Cell Growth Pathways. Plant Molecular Biology, 68, 225-237. http://dx.doi.org/10.1007/s11103-008-9364-y

[38] Zhenga, Y., Renb, N., Wanga, H., Strombergb, A.J. and Perrya, S.E. (2009) Global Identification of Targets of the Arabidopsis MADS Domain Protein AGAMOUS-Like15. The Plant Cell, 21, 2563-2577. http://dx.doi.org/10.1105/tpc.109.068890

[39] Shi, Y.L., Zhang, R., Wu, X.P., Meng, Z.G. and Guo, S. (2012) Cloning and Characterization of a Somatic Embryogenesis Receptor-Like Kinase Gene in Cotton (Gossypium hirsutum). Journal of Integrative Agriculture, 11, 898-909. http://dx.doi.org/10.1016/S2095-3119(12)60080-X

[40] Käll, L., Krogh, A. and Sonnhammer, E. (2004) A Combined Transmembrane Topology and Signal Peptide Prediction Method. Journal of Integrative Agriculture, 338, 1027-1036. http://dx.doi.org/10.1016/j.jmb.2004.03.016

[41] Dinkel, H., Michael, S., Weatheritt, R.J., Davey, N.E., Van Roey, K., Altenberg, B., et al. (2012) ELM-The Database of Eukaryotic Linear Motifs. Nucleic Acids Research, 40, D242-D251. http://dx.doi.org/10.1093/nar/gkr1064

[42] Dereeper, A., Guignon, V., Blanc, G., Audic, S., Buffet, S., Chevenet, F., Dufayard, J., Guindon, S., Lefort, V., Lescot, M., Claverie, J. and Gascuel, O. (2008) Phylogeny.fr: Robust Phylogenetic Analysis for the Non-Specialist. Nucleic Acids Research, 36, W465-W469. http://dx.doi.org/10.1093/nar/gkn180

[43] Kumar, S., Sharma, P. and Pental, D. (1998) A Genetic Approach to in Vitro Regeneration of Non-Regenerating Cotton (Gossypium hirsutum L.) Cultivars. Plant Cell Reports, 18, 59-63. http://dx.doi.org/10.1007/s002990050532

[44] Hemphill, J., Maier, C. and Chapman, K. (1998) Rapid in-Vitro Plant Regeneration of Cotton (Gossypium hirsutum L.). Plant Cell Reports, 17, 273-278. http://dx.doi.org/10.1007/s002990050391

[45] Dosztányi, Z., Csizmók, V., Tompa, P. and Simon, I. (2005) IUPred: Web Server for the Prediction of Intrinsically Unstructured Regions of Proteins Based on Estimated Energy Content. Bioinformatics, 21, 3433-3434. http://dx.doi.org/10.1093/bioinformatics/bti541

[46] Dosztányi, Z., Csizmók, V., Tompa, P. and Simon, I. (2005) The Pairwise Energy Content Estimated from Amino Acid Composition Discriminates between Folded and Intrinsically Unstructured Proteins. Journal of Molecular Biology, 347, 827-839. http://dx.doi.org/10.1016/j.jmb.2005.01.071

[47] Albrecht, C., Russinova, E., Hecht, V., Baaijens, E. and de Vries, S. (2005) The Arabidopsis thaliana Somatic Embryogenesis Receptor-Like Kinase1 and 2 Control Male Sporogenesis. The Plant Cell, 17, 3337-3349. http://dx.doi.org/10.1105/tpc.105.036814

[48] Diella, F., Haslam, N., Chica, C., Budd, A., Michael, S., Brown, N., Trave, G. and Gibson, T. (2008) Understanding Eukaryotic Linear Motifs and Their Role in Cell Signaling and Regulation. Frontiers in Bioscience, 13, 6580-6603. http://dx.doi.org/10.2741/3175

[49] Gibson, T. (2009) Cell Regulation: Determined to Signal Discrete Cooperation. Trends in Biochemical Sciences, 34, 471-482. http://dx.doi.org/10.1016/j.tibs.2009.06.007

[50] Davey, N., Van Roey, K., Weatheritt, R., Toedt, G., Uyar, B., Altenberg, B., Budd, A., Diella, F., Dinkel, H. and Gibson, T. (2011) Attributes of Short Linear Motifs. Molecular BioSystems, 8, 268-281. http://dx.doi.org/10.1039/c1mb05231d

[51] Bennett, E., Mandel, U., Clausen, H., Gerken, T., Fritz, T. and Tabak, L. (2011) Control of Mucin-Type O-Glycosylation: A Classification of the Polypeptide GalNAc-Transferase Gene Family. Glycobiology, 22, 736-756. http://dx.doi.org/10.1093/glycob/cwr182

[52] Poon, S., Heath, R. and Clarke, A.E. (2012) A Chimeric Arabinogalactan Protein Promotes Somatic Embryogenesis in Cotton Cell Culture. Plant Physiology, 160, 684-695. http://dx.doi.org/10.1104/pp.112.203075

[53] Pandey, D.K. and Chaudhary, B. (2014) Oxidative Stress Responsive SERK1 Gene Directs the Progression of Somatic Embryogenesis in Cotton (Gossypium hirsutum L. cv. Coker 310). American Journal of Plant Sciences, 5, 80-102. http://dx.doi.org/10.4236/ajps.2014.51012

[54] Sickmeier, M., Hamilton, J., LeGall, T., Vacic, V., Cortese, M., Tantos, A., Szabo, B., Tompa, P., Chen, J., Uversky, V., Obradovic, Z. and Dunker, A. (2007) DisProt: The Database of Disordered Proteins. Nucleic Acids Research, 35, D786-D793. http://dx.doi.org/10.1093/nar/gkl893 
[55] Tompa, P. (2002) Intrinsically Unstructured Proteins. Trends in Biochemical Sciences, 27, 527-533. http://dx.doi.org/10.1016/S0968-0004(02)02169-2

[56] Toorn, M., Huijbers, M., de Vries, S. and van Mierlo, C. (2012) The Arabidopsis thaliana SERK1 Kinase Domain Spontaneously Refolds to an Active State in Vitro. PLoS ONE, 7, e50907. http://dx.doi.org/10.1371/journal.pone.0050907

[57] Salaj, J., von Recklinghausen, I., Hecht, V., de Vries, S., Schel, J. and van Lammeren, A. (2008) AtSERK1 Expression Precedes and Coincides with Early Somatic Embryogenesis in Arabidopsis thaliana. Plant Physiology and Biochemistry, 46, 709-714. http://dx.doi.org/10.1016/j.plaphy.2008.04.011

[58] Azhakanandam, S., Nole-Wilson, S., Bao, F. and Franks, R. (2008) SEUSS and AINTEGUMENTA Mediate Patterning and Ovule Initiation during Gynoecium Medial Domain Development. Plant Physiology, 146, 1165-1181. http://dx.doi.org/10.1104/pp.107.114751

[59] Klucher, K., Chow, H., Reiser, L. and Fischer, R. (1996) The AINTEGUMENTA Gene of Arabidopsis Required for Ovule and Female Gametophyte Development Is Related to the Floral Homeotic Gene APETALA2. The Plant Cell, 8, 137-153. http://dx.doi.org/10.1105/tpc.8.2.137

[60] Mizukami, Y. and Fischer, R. (2000) Plant Organ Size Control: AINTEGUMENTA Regulates Growth and Cell Numbers during Organogenesis. Proceedings of the National Academy of Sciences of the United States of America, 97, 942947. http://dx.doi.org/10.1073/pnas.97.2.942

[61] Nole-Wilson, S., Tranby, T. and Krizek, B. (2005) AINTEGUMENTA-Like (AIL) Genes Are Expressed in Young Tissues and May Specify Meristematic or Division-Competent States. Plant Molecular Biology, 57, 613-628. http://dx.doi.org/10.1007/s11103-005-0955-6

[62] Nissen, P. (1994) Stimulation of Somatic Embryogenesis in Carrot by Ethylene: Effects of Modulators of Ethylene Biosynthesis and Action. Physiologia Plantarum, 92, 397-403. http://dx.doi.org/10.1111/j.1399-3054.1994.tb08827.x

[63] Reinhardt, D., Mandel, T. and Kuhlemeier, C. (2000) Auxin Regulates the Initiation and Radial Position of Plant Lateral Organs. The Plant Cell, 12, 507-518. http://dx.doi.org/10.1105/tpc.12.4.507

[64] Vernoux, T., Kronenberger, J., Grandjean, O., Laufs, P. and Traas, J. (2000) PIN-FORMED 1 Regulates Cell Fate at the Periphery of the Shoot Apical Meristem. Development, 127, 5157-5165.

[65] Chaudhary, B., Kumar, S., Prasad, K.V.S.K., Oinam, G.S., Burma, P.K. and Pental, D. (2003) Slow Desiccation Leads to High-Frequency Shoot Recovery from Transformed Somatic Embryos of Cotton (Gossypium hirsutum L. cv. Coker 310 FR). Plant Cell Reports, 21, 955-960. http://dx.doi.org/10.1007/s00299-003-0613-X

[66] Gou, X., Yin, H., He, K., Du, J., Yi, J., Xu, S., Lin, H., Clouse, S.D. and Li, J. (2012) Genetic Evidence for an Indispensable Role of Somatic Embryogenesis Receptor Kinases in Brassinosteroid Signaling. PLoS Genetics, 8, e1002452.

[67] He, K. (2008) Functional Analyses of Somatic Embryogenesis Receptor-Like Kinase Family in Multiple Signaling Pathways in Arabidopsis. Ph.D. Thesis, The University of Oklahoma, Norman, 143.

[68] Hu, H. and Brown, P.H. (1994) Localization of Boron in Cell Walls of Squash and Tobacco and Its Association with pectin. Plant Physiology, 105, 681-689.

[69] Nolan, K.E., Kurdyukov, S. and Rose, R.J. (2011) Characterisation of the Legume SERK-NIK Gene Superfamily Including Splice Variants: Implications for Development and Defence. BMC Plant Biology, 11, 44.

[70] Santa-Catarina, C., Hanai, L., Dornelas, M., Viana, A. and Floh, E.I.S. (2004) SERK Gene Homolog Expression, Polyamines and Amino Acids Associated with Somatic Embryogenic Competence of Ocotea catharinensis. Plant Cell, Tissue and Organ Culture, 79, 53-61. http://dx.doi.org/10.1023/B:TICU.0000049450.56271.f0

[71] Albertini, E., Marconi, G., Reale, L., Barcaccia, G., Porceddu, A., Ferranti, F. and Falcinelli, M. (2005) SERK and APOSTART. Candidate Gene for Apomixis in Poa pratensis. Plant Physiology, 138, 2185-2199. http://dx.doi.org/10.1104/pp.105.062059

[72] Talapatra, S., Ghoshal, N. and Raychaudhuri, S.S. (2014) Molecular Characterization, Modeling and Expression Analysis of a Somatic Embryogenesis Receptor Kinase (SERK) Gene in Momordica charantia L. during Somatic Embryogenesis. Plant Cell, Tissue and Organ Culture, 116, 271-283.

[73] Ge, X.X., Fan, G.E., Chai, L.J. and Guo, W.W. (2010) Cloning, Molecular Characterization and Expression Analysis of a SOMATIC EMBRYOGENESIS RECEPTOR-LIKE KINASE Gene (CitSERK1-Like) in Valencia Sweet Orange. Acta Physiologiae Plantarum, 32, 1197-1207. http://dx.doi.org/10.1007/s11738-010-0515-9

[74] Yang, C., Zhao, T., Yu, D. and Gai, J. (2011) Isolation and Functional Characterization of a SERK Gene from Soybean (Glycine max (L.) Merr.). Plant Molecular Biology Reporter, 29, 334-344. http://dx.doi.org/10.1007/s11105-010-0235-8

[75] Steiner, N., Santa-Catarina, C., Guerra, M.P., Cutri, L., Dornelas, M.C. and Floh, E.I.S. (2012) A Gymnosperm Homolog of SOMATIC EMBRYOGENESIS RECEPTOR-LIKE KINASE-1 (SERK1) Is Expressed during Somatic Em- 
bryogenesis. Plant Cell, Tissue and Organ Culture, 109, 41-50. http://dx.doi.org/10.1007/s11240-011-0071-z

[76] Cueva, A., Concia, L. and Cella, R. (2012) Molecular Characterization of a Cyrtochilum loxense Somatic Embryogenesis Receptor-Like Kinase (SERK) Gene Expressed during Somatic Embryogenesis. Plant Cell Reports, 31, 11291139. http://dx.doi.org/10.1007/s00299-012-1236-X 


\section{Supplementary}

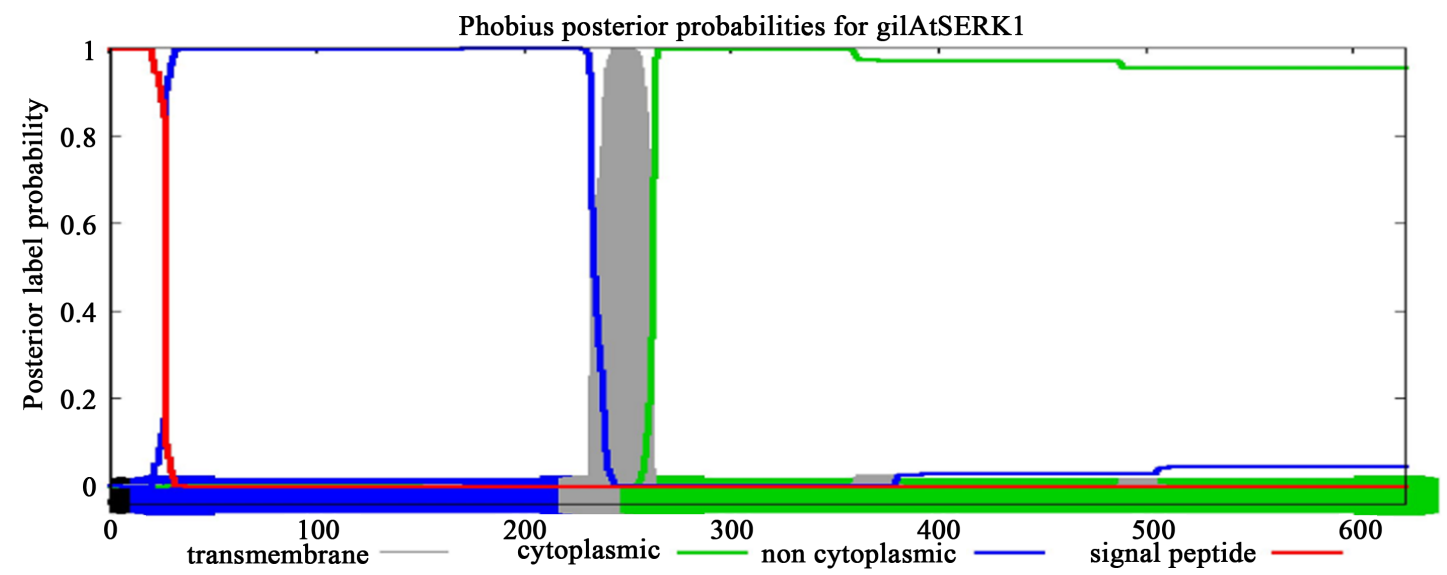

(A)

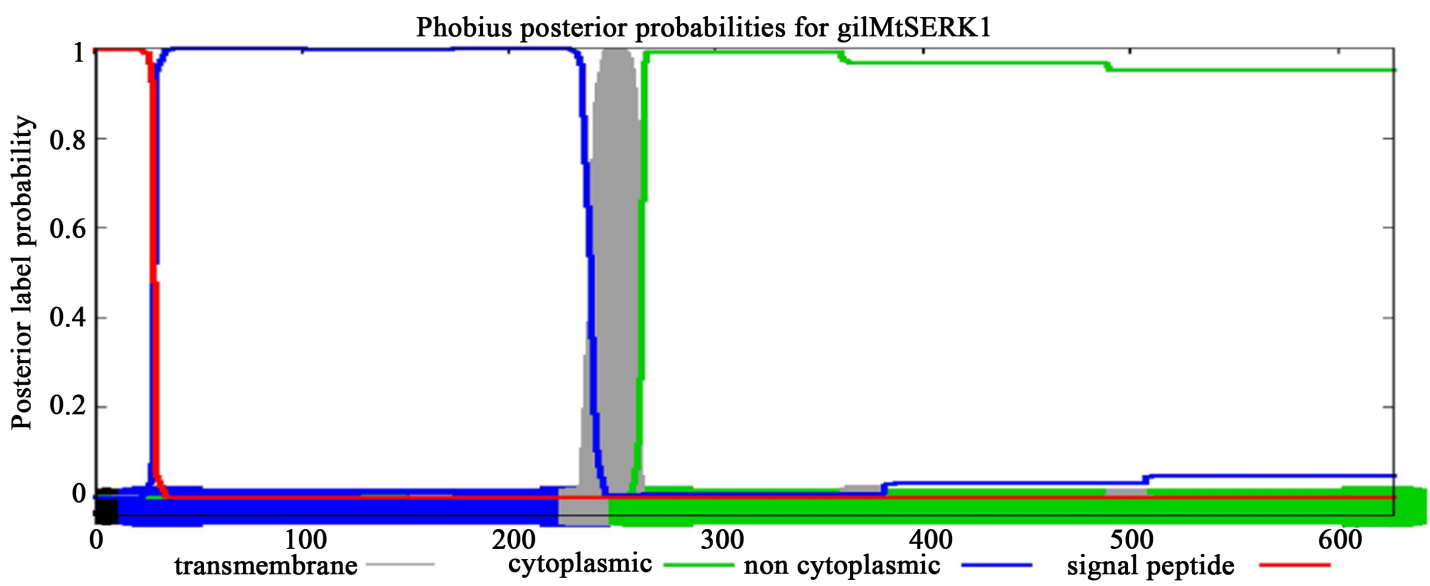

(B)

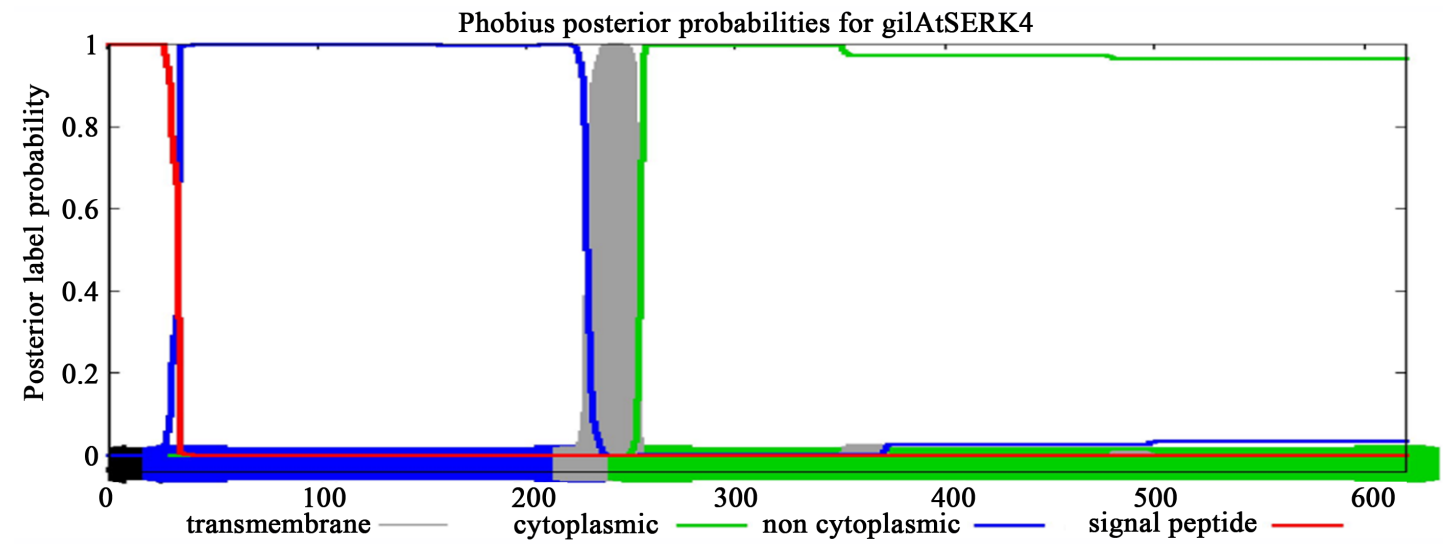

(C)

Figure S1. Prediction of transmembrane topology of SERK (AtSERK1, MtSERK1) and SERK-like (AtSERK4) proteins. 
Scientific Research Publishing (SCIRP) is one of the largest Open Access journal publishers. It is currently publishing more than 200 open access, online, peer-reviewed journals covering a wide range of academic disciplines. SCIRP serves the worldwide academic communities and contributes to the progress and application of science with its publication.

Other selected journals from SCIRP are listed as below. Submit your manuscript to us via either submit@scirp.org or Online Submission Portal.
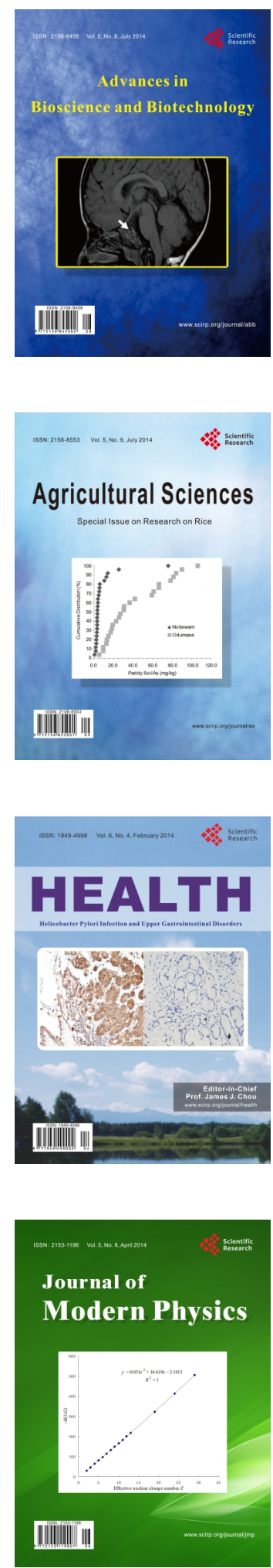
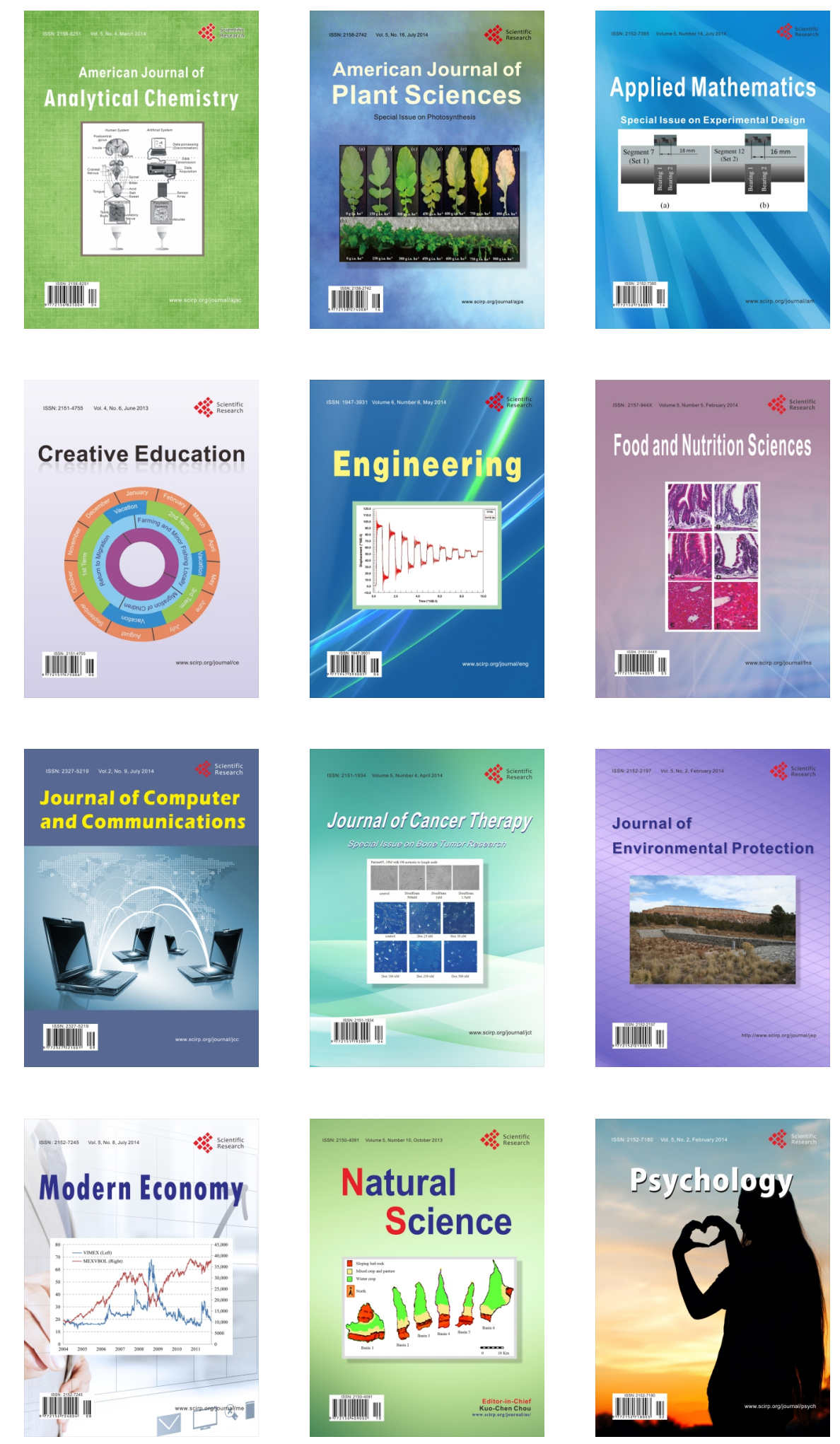